\title{
Perancangan Security Home (Keamanan pada Rumah) Menggunakan Mikrokontroller Berbasis SMS (Short Message Service)
}

\author{
Haris Isyanto ${ }^{1}$, Muhammad Syahrullah ${ }^{2}$ \\ 1,2) Jurusan TeknikElektro, Universitas Muhammadiyah Jakarta, Jakarta 10510 \\ E-mail: m.syahrullah.ms@gmail.com; haris.isyanto@ftumj.ac.id
}

\begin{abstract}
Abstrak
Rumah merupakan salah satu kebutuhan pokok dalam kehidupan manusia. Sebuah rumah harus menyediakan rasa aman bagi pemiliknya. Rumah selalu menjadi sasaran penjahat untuk melakukan pencurian terhadap rumah, rumah juga selalu mengalami insiden kebakaran, insiden kebanjiran dll. ketika pada saat di tinggal oleh pemilik rumah maka rumah tersebut menjadi sasaran penjahat untuk melakukan sebuah aksi pencurian. Aksi ini dapat menghilangkan barang - barang yang dianggap penting bagi pemilik rumah seperti barang elektronik, kendaraan dll. Untuk mengurangi hal tersebut dengan membuat security home (keamanan pada rumah) yang bisa monitoring keadaan rumah dapat dimonitoring oleh pemilik rumah dari insiden kejahatan, dan insiden dari gas bocor, kebakaran, dan kebanjiran. Dalam perancangan security home (keamanan pada rumah) dipasangkan sensor sensor yang sesuai kebutuhan dari segi pintu, pergerakan yang mencurigakan, detector gas, detector api, dan detector air. Ketika sensor tersebut aktif maka akan mengirimkan sebuah SMS (Short Message Service) supaya pemilik rumah mengetahui aktifitas dari sensor tersebut yang akan dikirim melalui handphone pemilik rumah tersebut. Hasil dari perancangan menghasilkan sebuah alat yang akan di pasang pada security home (keamanan pada rumah) yaitu RFID 1 dan RFID 2 yang di mana membuka sebuah pintu menggunakan kartu yang telah disetting oleh program dan ketika pintu tersebut terbuka kemudian pemilik rumah masuk maka akan menyalakan lampu, dan sebaliknya ketika pemilik rumah ini akan keluar maka akan menonaktifkan lampu menggunakan RFID, mendeteksi gerakan pada manusia (passive infrared) yang dipasangkan pada ruang tamu dan ruang kamar, detector api, detector air, dan detector gas. Ketika sensor detector aktif maka akan mengirimkan sebuah SMS (short message service) ke handphone pemilik rumah.
\end{abstract}

Kata kunci :Security Home, Sensor RFID, Sensor Passive Infrared HC-SR05, sensor api, sensor gas, sensor air. SMS (Short Message Service

\section{PENDAHULUAN}

Rumah merupakan salah satu kebutuhan pokok dalam kehidupan manusia. Sebuah rumah harus aman dari segala bahaya seperti pencurian, kebakaran yang diakibatkan gas bocor. Pada penelitian yang kami lakukan membuat suatu keamanan rumah (Security Home) berbasis SMS menggunakan Arduino. Security home ini mencegah pemakaian lebih pada listrik, mencegah pencurian dalam rumah, dan mencegah kebakaran pada rumah. Konsep rumah cerdas menawarkan suasana yang nyaman dan praktis bagi penghuninya [1]. Komponen dari security home ini terdiri dari sensor RFID, sensor Passive Infrared, sensor api, sensor gas, sensor air. System tersebut dilengkapi dengan SMS apabila sensor gerak dari Passive Infrared, Sensor Api, Sensor Air, Sensor Gas terdeteksi maka akan mengirimkan SMS ke handphone pemilik rumah ketika ada gangguan terhadap rumah dan mengaktifkan buzzer. Security home ini juga mencegah dari pemakaian listrik berlebih menggunakan system RFID. Dimana RFID ini di pasang dengan 2 RFID, RFID pertama berfungsi sebagai membuka pintu secara automatis dengan RFID card ketika RFID terdeteksi maka akan membuka pintu untuk masuk, kemudian akan menyalakan lampu, ketika akan keluar dari rumah maka menggunakan system RFID 2 yang berfungsi untuk akses keluar rumah dan menonaktifkan lampu. Jaringan-jaringan sensor ada dimana-mana dan mereka dianggap sebuah system yang rumit untuk manufaktur dan aplikasi medis, tetapi mereka tidak selalu rumit [2]. Penerapan pemantau polusi ruangan dengan menggunakan SMS memudahkan para pengguna untuk mengetahui keadaan ruangan [3]. Arduino merupakan perangkat keras sekaligus perangkat lunak yang memudahkan membuat prototype rangkaian elektronika [4]. Gas alam juga berbahaya jika ditransportasikan dengan ceroboh [5].

Dalam pengerjaan penelitian ini terdapat beberapa permasalahan yang dihadapi dalam perancangan dan realisasi system, diantaranya adalah sebagai berikut: 
RESISTOR (elektRonika kEndali telekomunikaSI tenaga liSTrik kOmputeR) Vol. 1 No. 2 e-ISSN : 2621-9700, p-ISSN : 2654-2684

1. Pemilihan dan perancangan perangkat keras yang sesuai dengan spesifikasi yang direalisasikan supaya tercapai security home.

2. Pemilihan komponen yang sesuai dengan spesifikasi yang direalisasikan

3. Merancang program untuk menjalankan security home

4. Pemilihan komponen SMS modul supaya sesuai dengan spesifikasi yang direalisasikan.

Dalam penelitian ini permasalahan yang dibahas dibatasi pada perancangan perangkat keras maupun lunak. Ruang lingkup. Ruang lingkup permasalahan tersebut terbagi atas beberapa point, yaitu:

1. Perangkat keras sensor untuk dapat menjalankan semua system.

2. Perangkat lunak pemograman supaya bisa berjalan security home.

3. Penempatan masalah pada suatu ruangan yang akan dijadikan tempat security home tersebut.

Tujuan penelitian ini membuat sebuah rancangan pada security home untuk monitoring keadaan rumah maupun mengendalikan elektronik seperti: pintu menggunakan rfid lock sensor untuk pintu dan mengendalikan lampu secara automatis, membaca gerakan seseorang menggunakan sensor pir, detector pada sensor api, detector pada sensor gas, detector pada sensor air.

\section{LANDASAN TEORI}

Security home adalah sebuah rumah yang di desain untuk menjaga kemanan rumah melalui perangkat keras maupun perangkat lunak untuk memberikan keamanan dari segi pintu, system alarm, detector gerak (passive infrared), detector api, gas, maupun air. Yang dimana system ini terintegrasi melalui perangkat lunak untuk memberikan informasi terkait aktifitas mencurigakan. Security home ini melindungi dari segi aktifitas pencurian yang akan mengakibatkan kehilangan barang, kebakaran, kebocoran gas, alarm kebanjiran, keamanan pintu rumah.

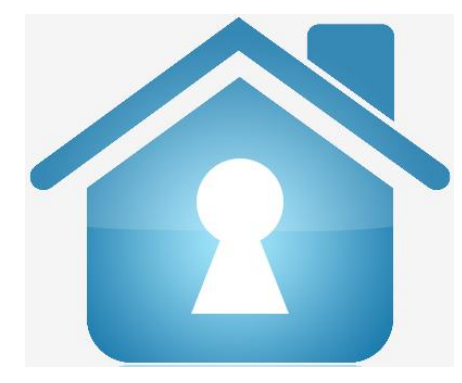

Gambar 1. Security home.

\section{Flowchart Security Home (Keamanan Rumah)}

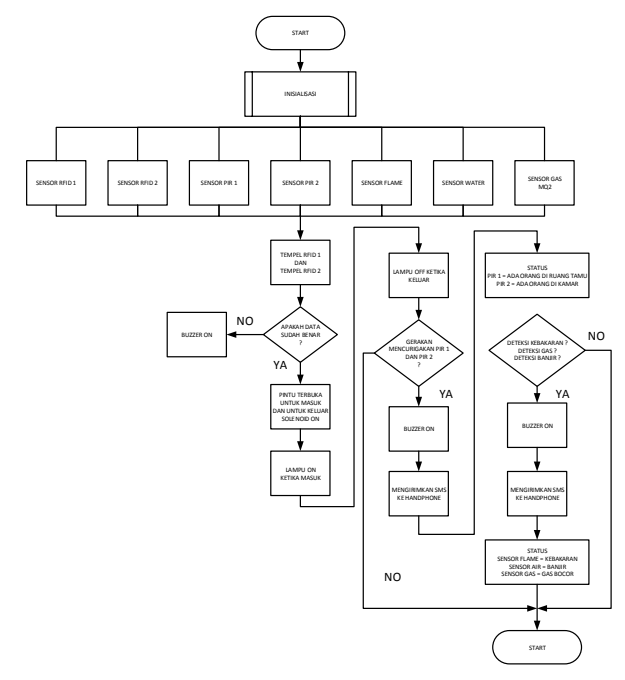

Gambar 2. Flowchart security home

Fungsi flowchart sistem ini sebagai sistem security home. Sistem ini berkerja apabila semua inputan dari segi sensor. Sistem ini menggerakkan sebuah RFID 1 lock sensor dan RFID 2 untuk membuka sebuah pintu masuk apabila user menempelkan sebuah RFID 1, dan RFID 2 card data yang ada RFID ini sudah terdaftar di sistem ketika belom terdaftar maka tidak akan membuka sebuah pintu, kemudian setelah RFID 1 itu aktif maka mengaktifkan solenoid, dan pintu masuk akan terbuka. Kemudian mengaktifkan sebuah relay untuk menyalakan sebuah lampu. Kemudian RFID 2 itu aktif maka mengaktifkan solenoid, dan pintu keluar akan terbuka. Kemudian menonaktifkan sebuah Relay lampu ini menonaktifkan sebuah lampu ketika akan keluar dari rumah. Sensor PIR 1 dan PIR 2 untuk mendeteksi sebuah pergerakan manusia. Apabila pir 1 dan pir 2 aktif maka akan mengirimkan sebuah SMS dengan status PIR 1 "ada orang di ruang tamu", dan status PIR 2 "ada orang di kamar". Ketika PIR 1, dan PIR 2 aktif maka akan mengaktifkan sebuah BUZZER sebagai penanda ada orang yang mencurigakan. Sensor api, sensor water, dan sensor gas untuk mendeteksi api, mendeteksi banjir, dan mendeteksi gas bocor. Ketika sensor aktif maka akan mengirimkan SMS dengan status sensor api "kebakaran", sensor water "banjir", dan sensor gas "gas bocor". Ketika sensor tersebut aktif maka akan mengaktifkan sebuah buzzer. Semua notifikasi tersebut akan mengirimkan SMS ke handphone pemilik rumah. Kebocoran gas sangat berbahaya karena dapat menyulut terjadinya kebakaran [6].

Prinsip kerja dari security home ini adalah semua sensor akan dibaca oleh arduino yang kemudian datanya diproses dan dianalisa. Data 
RESISTOR (elektRonika kEndali telekomunikaSI tenaga liSTrik kOmputeR) Vol. 1 No. 2 e-ISSN : 2621-9700, p-ISSN : 2654-2684

tersebut akan dikirim SMS ke handphone pemilik rumah. Dalam proses pembuatannya dibagi beberapa rangkaian blok yaitu:

1. Design security home.

2. Rangkaian sensor RFID 1 dan Rangkaian sensor RFID 2.

3. Rangkaian sensor PIR1, dan sensor PIR2.

4. Rangkaian sensor Api. Sensor Api mampu mendeteksi keberadaan api [7].

5. Rangkaian sensor water.

6. Rangkaian sensor gas.

Maksud dari blok diagram security home ini yaitu sebuah inputan sensor dari sensor RFID 1, sensor RFID 2, sensor PIR1, sensor PIR2, sensor flame, sensor water, sensor dan gas MQ2. Sensor gas MQ2 merupakan alat yang bisa mendeteksi asap [8]. Ketika sensor tersebut terdeteksi maka akan mengirimkan sinyal ke Arduino kemudian di proses ke SIM 800L untuk mengirimkan sebuah notifikasi berupa sms setiap terdeteksi kecuali sensor RFID 1, dan sensor RFID2 tidak mengirimkan sebuah SMS ke handphone pemilik. Semua inputan sensor akan komunikasi ke Arduino. Berikut adalah blok diagram security home.

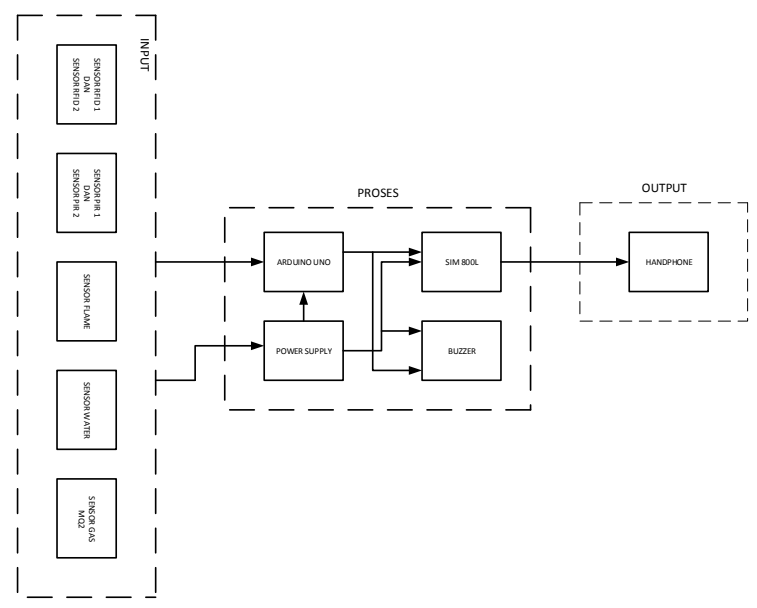

Gambar 3. Blok diagram security home.

Design security home berfungsi sebagai penempatan dari semua perangkat sensor yang akan dipasang untuk menjalankan suatu perangkat dengan sensor RFID sebagai membuka akses pintu masuk dan pintu keluar secara automatis degan di tempelkan sebuah RFID card, membaca deteksi gerakan manusia dengan sensor passive infrared 1 di pasangkan di ruang tamu, dan sensor passive infrared 2 dipasangkan di ruang kamar, sensor api untuk mendeteksi api, sensor water untuk mendeteksi air dengan status banjir, dan sensor gas untuk mendetksi suatu gas apabila terjadi nya kebocoran pada tabung gas. Berikut adalah sebuah design dari security home :

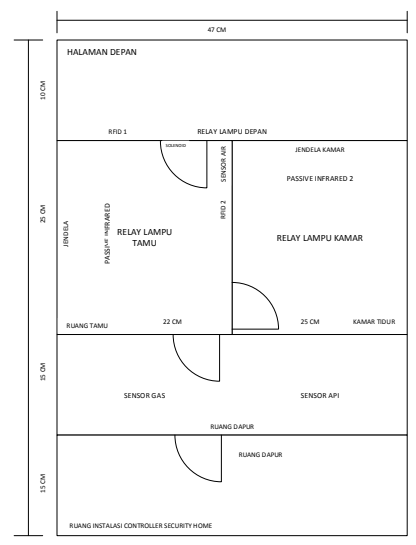

Gambar 4. Design security home

\section{PENGUJIAN DAN ANALISA}

Pada bab pengujian dan analisa ini dilakukan supaya dapat mengetahui apakah alat yang dirancang bekerja sesuai dengan alat yang diharapkan atau tidak atau tidak. Pengujian dilakukan pada perangkat keras dan perangkat lunak.

Pada Pengujian sensor RFID 1 ini untuk mengukur jarak sensor RFID terhadap RFID tag. Di dalam RFID tag ini di program untuk bisa mengakses pintu dengan sensor RFID. Pengujian sensor RFID terhadap RFID tag akan di uji dari jarak $0 \mathrm{~cm}$ sampai dengan jarak kritis antara sensor RFID terhadap RFID tag supaya bisa mengakses pintu tersebut. Pintu akan terbuka apabila Solenoid nya dalam keadaan menyala. Pengujian ini untuk mengakses sebuah pintu masuk ketika dapat akses masuk akan mengaktifkan sebuah solenoid dan mengaktifkan sebuah lampu. Apabila tidak dapat akses maka tidak akan membuka pintu dan menyalakan sebuah buzzer. Berikut adalah gambar pengujian RFID Lock Sensor.

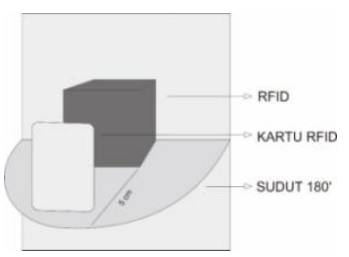

Gambar 5. Ilustrasi pengujian rangkaian sensor RFID 1

Tabel 1. Pengujian Sudut RFID Lock Sensor pada 5 $\mathrm{cm}$

\begin{tabular}{|c|c|c|c|c|c|}
\hline $\mathrm{N}$ & $\mathrm{Su}$ & Respo & $\mathrm{S}$ & $\mathrm{L}$ & Status \\
$\mathrm{o}$ & $\mathrm{du}$ & $\mathrm{n}$ & $\mathrm{o}$ & $\mathrm{a}$ & Pintu \\
& $\mathrm{t}$ & sensor & $\mathrm{I}$ & $\mathrm{m}$ & \\
\hline
\end{tabular}


RESISTOR (elektRonika kEndali telekomunikaSI tenaga liSTrik kOmputeR) Vol. 1 No. 2 e-ISSN : 2621-9700, p-ISSN : 2654-2684

\begin{tabular}{|c|c|c|c|c|c|}
\hline & $\begin{array}{l}\text { RF } \\
\text { ID } \\
\text { TA } \\
\text { G }\end{array}$ & & $\begin{array}{l}\mathrm{e} \\
\mathrm{n} \\
\mathrm{o} \\
\mathrm{i} \\
\mathrm{d}\end{array}$ & $\begin{array}{l}p \\
u\end{array}$ & \\
\hline 1 & $0^{\circ}$ & $\begin{array}{c}\text { Mend } \\
\text { eteksi } \\
\text { RFID } \\
\text { TAG }\end{array}$ & $\begin{array}{l}\mathrm{O} \\
\mathrm{N}\end{array}$ & $\begin{array}{l}\mathrm{O} \\
\mathrm{N}\end{array}$ & Terbuka \\
\hline 2 & $\begin{array}{c}10 \\
0\end{array}$ & $\begin{array}{c}\text { Mend } \\
\text { eteksi } \\
\text { RFID } \\
\text { TAG }\end{array}$ & $\begin{array}{l}\mathrm{O} \\
\mathrm{N}\end{array}$ & $\begin{array}{l}\mathrm{O} \\
\mathrm{N}\end{array}$ & Terbuka \\
\hline 3 & $\begin{array}{c}20 \\
0\end{array}$ & $\begin{array}{c}\text { Mend } \\
\text { eteksi } \\
\text { RFID } \\
\text { TAG }\end{array}$ & $\begin{array}{l}\mathrm{O} \\
\mathrm{N}\end{array}$ & $\begin{array}{l}\mathrm{O} \\
\mathrm{N}\end{array}$ & Terbuka \\
\hline 4 & $\begin{array}{c}30 \\
0\end{array}$ & $\begin{array}{c}\text { Mend } \\
\text { eteksi } \\
\text { RFID } \\
\text { TAG }\end{array}$ & $\begin{array}{l}\mathrm{O} \\
\mathrm{N}\end{array}$ & $\begin{array}{l}\mathrm{O} \\
\mathrm{N}\end{array}$ & Terbuka \\
\hline 5 & $\begin{array}{c}40 \\
0\end{array}$ & $\begin{array}{c}\text { Mend } \\
\text { eteksi } \\
\text { RFID } \\
\text { TAG }\end{array}$ & $\begin{array}{l}\mathrm{O} \\
\mathrm{N}\end{array}$ & $\begin{array}{l}\mathrm{O} \\
\mathrm{N}\end{array}$ & Terbuka \\
\hline 6 & $\begin{array}{c}50 \\
0\end{array}$ & $\begin{array}{c}\text { Mend } \\
\text { eteksi } \\
\text { RFID } \\
\text { TAG }\end{array}$ & $\begin{array}{l}\mathrm{O} \\
\mathrm{N}\end{array}$ & $\begin{array}{l}\mathrm{O} \\
\mathrm{N}\end{array}$ & Terbuka \\
\hline 7 & $\begin{array}{c}60 \\
\circ\end{array}$ & $\begin{array}{c}\text { Mend } \\
\text { eteksi } \\
\text { RFID } \\
\text { TAG }\end{array}$ & $\begin{array}{l}\mathrm{O} \\
\mathrm{N}\end{array}$ & $\begin{array}{l}\mathrm{O} \\
\mathrm{N}\end{array}$ & Terbuka \\
\hline 8 & $\begin{array}{c}70 \\
0\end{array}$ & $\begin{array}{c}\text { Tdk } \\
\text { Mend } \\
\text { eteksi } \\
\text { RFID } \\
\text { TAG }\end{array}$ & $\begin{array}{l}\mathrm{O} \\
\mathrm{F} \\
\mathrm{F}\end{array}$ & $\begin{array}{l}\mathrm{O} \\
\mathrm{F} \\
\mathrm{F}\end{array}$ & $\begin{array}{c}\text { Tdk } \\
\text { Terbuka }\end{array}$ \\
\hline 9 & $\begin{array}{c}80 \\
0\end{array}$ & $\begin{array}{c}\text { Tdk } \\
\text { Mend } \\
\text { eteksi } \\
\text { RFID } \\
\text { TAG }\end{array}$ & $\begin{array}{l}\mathrm{O} \\
\mathrm{F} \\
\mathrm{F}\end{array}$ & $\begin{array}{l}\mathrm{O} \\
\mathrm{F} \\
\mathrm{F}\end{array}$ & $\begin{array}{c}\text { Tdk } \\
\text { Terbuka }\end{array}$ \\
\hline $\begin{array}{l}1 \\
0\end{array}$ & $\begin{array}{c}90 \\
0\end{array}$ & $\begin{array}{c}\text { Tdk } \\
\text { Mend } \\
\text { eteksi } \\
\text { RFID }\end{array}$ & $\begin{array}{l}\mathrm{O} \\
\mathrm{F} \\
\mathrm{F}\end{array}$ & $\begin{array}{l}\mathrm{O} \\
\mathrm{F} \\
\mathrm{F}\end{array}$ & $\begin{array}{c}\text { Tdk } \\
\text { Terbuka }\end{array}$ \\
\hline
\end{tabular}

\begin{tabular}{|c|c|c|c|c|c|}
\hline & & TAG & & & \\
\hline 1 & 10 & Tdk & 0 & $\mathrm{O}$ & Tdk \\
\hline 1 & $0^{\circ}$ & Mend & $F$ & $F$ & Terbuka \\
\hline & & eteksi & $F$ & $F$ & \\
\hline & & RFID & & & \\
\hline & & TAG & & & \\
\hline 1 & 12 & Tdk & 0 & 0 & Tdk \\
\hline \multirow[t]{4}{*}{2} & $0^{\circ}$ & Mend & $F$ & $F$ & Terbuka \\
\hline & & eteksi & $\mathrm{F}$ & $\mathrm{F}$ & \\
\hline & & RFID & & & \\
\hline & & TAG & & & \\
\hline 1 & 13 & Mend & 0 & 0 & Terbuka \\
\hline \multirow[t]{3}{*}{3} & $0^{\circ}$ & eteksi & $\mathrm{N}$ & $\mathrm{N}$ & \\
\hline & & RFID & & & \\
\hline & & TAG & & & \\
\hline 1 & 14 & Mend & 0 & 0 & Terbuka \\
\hline \multirow[t]{3}{*}{4} & $0^{\circ}$ & eteksi & $\mathrm{N}$ & $\mathrm{N}$ & \\
\hline & & RFID & & & \\
\hline & & TAG & & & \\
\hline 1 & 15 & Mend & 0 & 0 & Terbuka \\
\hline \multirow[t]{3}{*}{5} & $0^{\circ}$ & eteksi & $\mathrm{N}$ & $\mathrm{N}$ & \\
\hline & & RFID & & & \\
\hline & & TAG & & & \\
\hline 1 & 16 & Mend & 0 & 0 & Terbuka \\
\hline \multirow[t]{3}{*}{6} & $0^{\circ}$ & eteksi & $\mathrm{N}$ & $\mathrm{N}$ & \\
\hline & & RFID & & & \\
\hline & & TAG & & & \\
\hline 1 & 17 & Mend & 0 & 0 & Terbuka \\
\hline \multirow[t]{3}{*}{7} & $0^{\circ}$ & eteksi & $\mathrm{N}$ & $\mathrm{N}$ & \\
\hline & & RFID & & & \\
\hline & & TAG & & & \\
\hline 1 & 18 & Mend & 0 & 0 & Terbuka \\
\hline \multirow[t]{3}{*}{8} & $0^{\circ}$ & eteksi & $\mathrm{N}$ & $\mathrm{N}$ & \\
\hline & & RFID & & & \\
\hline & & TAG & & & \\
\hline
\end{tabular}


RESISTOR (elektRonika kEndali telekomunikaSI tenaga liSTrik kOmputeR) Vol. 1 No. 2 e-ISSN : 2621-9700, p-ISSN : 2654-2684

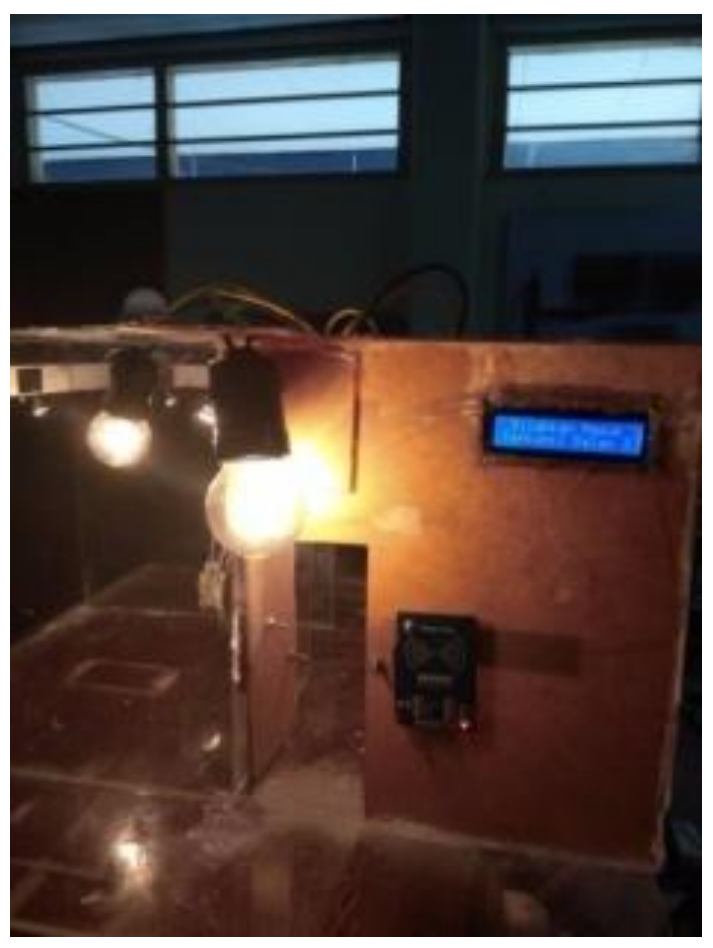

Gambar 6. Tampilan respon RFID 1 ketika masuk pintu akan mengaktifkan lampu

Pada Pengujian sensor RFID 2 ini untuk mengukur jarak sensor RFID terhadap RFID tag. Di dalam RFID tag ini di program untuk bisa mengakses pintu dengan sensor RFID. Pengujian sensor RFID terhadap RFID tag akan di uji dari jarak $0 \mathrm{~cm}$ sampai dengan jarak kritis antara sensor RFID terhadap RFID tag supaya bisa mengakses pintu tersebut. Pintu akan terbuka apabila Solenoid nya dalam keadaan menyala. Pengujian ini untuk mengakses sebuah pintu keluar rumah ketika dapat akses untuk keluar rumah akan mengaktifkan sebuah solenoid dan menonaktifkan sebuah lampu. Berikut adalah gambar pengujian RFID Lock Sensor. Apabila tidak dapat akses maka tidak akan membuka pintu dan menyalakan sebuah buzzer.

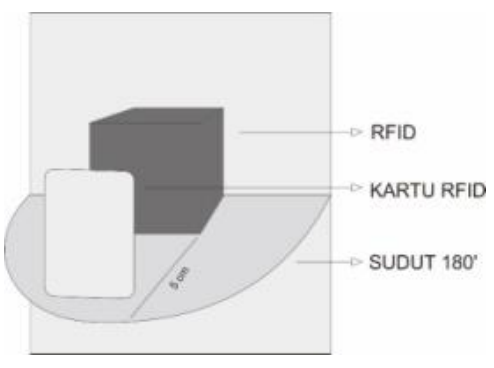

Gambar 7. Ilustrasi pengujian rangkaian sensor RFID 2

Tabel 2. Pengujian Sudut RFID Lock Sensor pada 5 $\mathrm{cm}$

\begin{tabular}{|c|c|c|c|c|c|}
\hline $\begin{array}{l}\mathrm{N} \\
\mathrm{O}\end{array}$ & $\begin{array}{c}\mathrm{Su} \\
\mathrm{du} \\
\mathrm{t} \\
\mathrm{RF} \\
\mathrm{ID} \\
\mathrm{TA} \\
\mathrm{G}\end{array}$ & $\begin{array}{c}\text { Respo } \\
n \\
\text { sensor }\end{array}$ & $\begin{array}{l}\mathrm{S} \\
\mathrm{o} \\
\mathrm{I} \\
\mathrm{e} \\
\mathrm{n} \\
\mathrm{o} \\
\mathrm{i} \\
\mathrm{d}\end{array}$ & $\begin{array}{c}\mathrm{L} \\
\mathrm{a} \\
\mathrm{m} \\
\mathrm{p} \\
\mathrm{u}\end{array}$ & $\begin{array}{c}\text { Status } \\
\text { Pintu }\end{array}$ \\
\hline 1 & $0^{\circ}$ & $\begin{array}{c}\text { Mend } \\
\text { eteksi } \\
\text { RFID } \\
\text { TAG }\end{array}$ & $\begin{array}{l}\mathrm{O} \\
\mathrm{N}\end{array}$ & $\begin{array}{l}\mathrm{O} \\
\mathrm{N}\end{array}$ & Terbuka \\
\hline 2 & $\begin{array}{c}10 \\
\circ\end{array}$ & $\begin{array}{c}\text { Mend } \\
\text { eteksi } \\
\text { RFID } \\
\text { TAG }\end{array}$ & $\begin{array}{l}\mathrm{O} \\
\mathrm{N}\end{array}$ & $\begin{array}{l}\mathrm{O} \\
\mathrm{N}\end{array}$ & Terbuka \\
\hline 3 & $\begin{array}{c}20 \\
0\end{array}$ & $\begin{array}{c}\text { Mend } \\
\text { eteksi } \\
\text { RFID } \\
\text { TAG }\end{array}$ & $\begin{array}{l}\mathrm{O} \\
\mathrm{N}\end{array}$ & $\begin{array}{l}\mathrm{O} \\
\mathrm{N}\end{array}$ & Terbuka \\
\hline 4 & $\begin{array}{c}30 \\
\circ\end{array}$ & $\begin{array}{c}\text { Mend } \\
\text { eteksi } \\
\text { RFID } \\
\text { TAG }\end{array}$ & $\begin{array}{l}\mathrm{O} \\
\mathrm{N}\end{array}$ & $\begin{array}{l}\mathrm{O} \\
\mathrm{N}\end{array}$ & Terbuka \\
\hline 5 & $\begin{array}{c}40 \\
\circ\end{array}$ & $\begin{array}{c}\text { Mend } \\
\text { eteksi } \\
\text { RFID } \\
\text { TAG }\end{array}$ & $\begin{array}{l}\mathrm{O} \\
\mathrm{N}\end{array}$ & $\begin{array}{l}\mathrm{O} \\
\mathrm{N}\end{array}$ & Terbuka \\
\hline 6 & $\begin{array}{c}50 \\
\circ\end{array}$ & $\begin{array}{c}\text { Mend } \\
\text { eteksi } \\
\text { RFID } \\
\text { TAG }\end{array}$ & $\begin{array}{l}\mathrm{O} \\
\mathrm{N}\end{array}$ & $\begin{array}{l}\mathrm{O} \\
\mathrm{N}\end{array}$ & Terbuka \\
\hline 7 & $\begin{array}{c}60 \\
\circ\end{array}$ & $\begin{array}{c}\text { Mend } \\
\text { eteksi } \\
\text { RFID } \\
\text { TAG }\end{array}$ & $\begin{array}{l}\mathrm{O} \\
\mathrm{N}\end{array}$ & $\begin{array}{l}\mathrm{O} \\
\mathrm{N}\end{array}$ & Terbuka \\
\hline 8 & $\begin{array}{c}70 \\
\circ\end{array}$ & $\begin{array}{c}\text { Tdk } \\
\text { Mend } \\
\text { eteksi } \\
\text { RFID } \\
\text { TAG }\end{array}$ & $\begin{array}{l}\mathrm{O} \\
\mathrm{F} \\
\mathrm{F}\end{array}$ & $\begin{array}{l}\mathrm{O} \\
\mathrm{F} \\
\mathrm{F}\end{array}$ & $\begin{array}{c}\text { Tdk } \\
\text { Terbuka }\end{array}$ \\
\hline 9 & $\begin{array}{c}80 \\
\circ\end{array}$ & $\begin{array}{c}\text { Tdk } \\
\text { Mend } \\
\text { eteksi } \\
\text { RFID } \\
\text { TAG }\end{array}$ & $\begin{array}{l}\mathrm{O} \\
\mathrm{F} \\
\mathrm{F}\end{array}$ & $\begin{array}{l}\mathrm{O} \\
\mathrm{F} \\
\mathrm{F}\end{array}$ & $\begin{array}{c}\text { Tdk } \\
\text { Terbuka }\end{array}$ \\
\hline 1 & 90 & Tdk & 0 & 0 & Tdk \\
\hline
\end{tabular}


RESISTOR (elektRonika kEndali telekomunikaSI tenaga liSTrik kOmputeR) Vol. 1 No. 2 e-ISSN : 2621-9700, p-ISSN : 2654-2684

\begin{tabular}{|c|c|c|c|c|c|}
\hline 0 & 0 & $\begin{array}{c}\text { Mend } \\
\text { eteksi } \\
\text { RFID } \\
\text { TAG }\end{array}$ & $\begin{array}{l}F \\
F\end{array}$ & $\begin{array}{l}F \\
F\end{array}$ & Terbuka \\
\hline $\begin{array}{l}1 \\
1\end{array}$ & $\begin{array}{l}10 \\
0^{\circ}\end{array}$ & $\begin{array}{c}\text { Tdk } \\
\text { Mend } \\
\text { eteksi } \\
\text { RFID } \\
\text { TAG }\end{array}$ & $\begin{array}{l}\text { O } \\
F \\
F\end{array}$ & $\begin{array}{l}O \\
F \\
F\end{array}$ & $\begin{array}{c}\text { Tdk } \\
\text { Terbuka }\end{array}$ \\
\hline $\begin{array}{l}1 \\
2\end{array}$ & $\begin{array}{l}12 \\
0^{\circ}\end{array}$ & $\begin{array}{c}\text { Tdk } \\
\text { Mend } \\
\text { eteksi } \\
\text { RFID } \\
\text { TAG }\end{array}$ & $\begin{array}{l}\mathrm{O} \\
\mathrm{F} \\
\mathrm{F}\end{array}$ & $\begin{array}{l}\text { O } \\
F \\
F\end{array}$ & $\begin{array}{c}\text { Tdk } \\
\text { Terbuka }\end{array}$ \\
\hline $\begin{array}{l}1 \\
3\end{array}$ & $\begin{array}{l}13 \\
0^{\circ}\end{array}$ & $\begin{array}{l}\text { Mend } \\
\text { eteksi } \\
\text { RFID } \\
\text { TAG }\end{array}$ & $\begin{array}{l}\mathrm{O} \\
\mathrm{N}\end{array}$ & $\begin{array}{l}\mathrm{O} \\
\mathrm{N}\end{array}$ & Terbuka \\
\hline $\begin{array}{l}1 \\
4\end{array}$ & $\begin{array}{l}14 \\
0^{\circ}\end{array}$ & $\begin{array}{l}\text { Mend } \\
\text { eteksi } \\
\text { RFID } \\
\text { TAG }\end{array}$ & $\begin{array}{l}\mathrm{O} \\
\mathrm{N}\end{array}$ & $\begin{array}{l}\mathrm{O} \\
\mathrm{N}\end{array}$ & Terbuka \\
\hline $\begin{array}{l}1 \\
5\end{array}$ & $\begin{array}{l}15 \\
0^{\circ}\end{array}$ & $\begin{array}{c}\text { Mend } \\
\text { eteksi } \\
\text { RFID } \\
\text { TAG }\end{array}$ & $\begin{array}{l}\mathrm{O} \\
\mathrm{N}\end{array}$ & $\begin{array}{l}\mathrm{O} \\
\mathrm{N}\end{array}$ & Terbuka \\
\hline $\begin{array}{l}1 \\
6\end{array}$ & $\begin{array}{l}16 \\
0^{\circ}\end{array}$ & $\begin{array}{c}\text { Mend } \\
\text { eteksi } \\
\text { RFID } \\
\text { TAG }\end{array}$ & $\begin{array}{l}\mathrm{O} \\
\mathrm{N}\end{array}$ & $\begin{array}{l}\mathrm{O} \\
\mathrm{N}\end{array}$ & Terbuka \\
\hline $\begin{array}{l}1 \\
7\end{array}$ & $\begin{array}{l}17 \\
0^{\circ}\end{array}$ & $\begin{array}{l}\text { Mend } \\
\text { eteksi } \\
\text { RFID } \\
\text { TAG }\end{array}$ & $\begin{array}{l}\mathrm{O} \\
\mathrm{N}\end{array}$ & 0 & Terbuka \\
\hline $\begin{array}{l}1 \\
8\end{array}$ & $\begin{array}{l}18 \\
0^{\circ}\end{array}$ & $\begin{array}{c}\text { Mend } \\
\text { eteksi } \\
\text { RFID } \\
\text { TAG }\end{array}$ & $\begin{array}{l}\mathrm{O} \\
\mathrm{N}\end{array}$ & $\begin{array}{l}\mathrm{O} \\
\mathrm{N}\end{array}$ & Terbuka \\
\hline
\end{tabular}

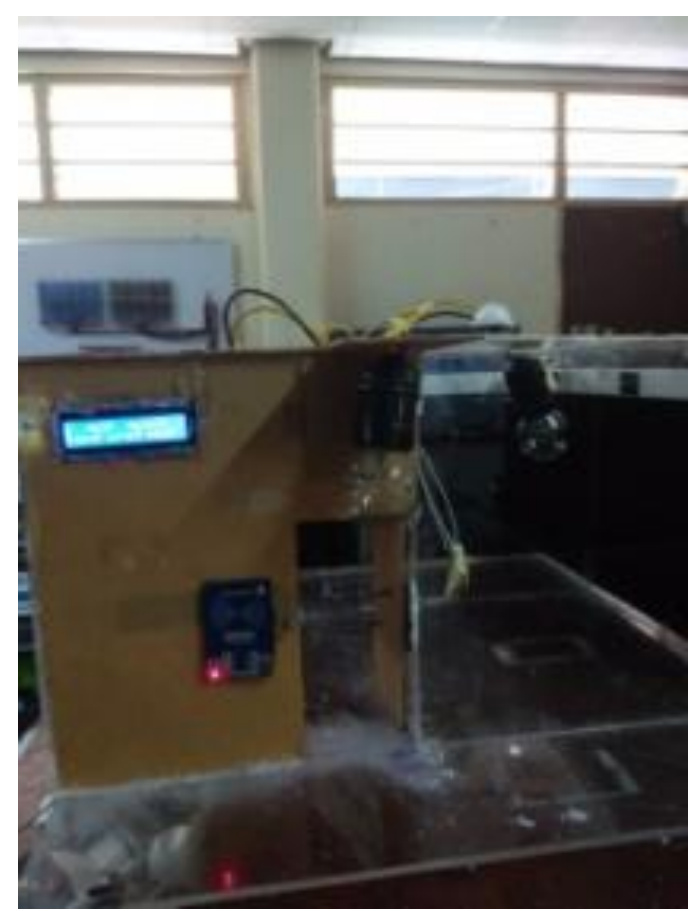

Gambar 8. Tampilan respon RFID 2 ketika keluar pintu akan menonaktifkan lampu

Pada pengujian sensor Passive Infrared (PIR) ini ditujukan untuk mengetahui respon jarak terhadap pergerakan manusia yang ada didalam ruangan tersebut. Dalam pengujian sensor Passiver Infrared (PIR) yaitu dengan menguji jarak pergerakan manusia dari $10 \mathrm{~cm}$ sampai jarak kritis dari sensor Passive Infrared dengan nilai jarak kritis $110 \mathrm{~cm}$. pengujian ini ada dua passive infrared, passive infrared 1 mendeteksi sebuah gerakan manusia pada ruang tamu. Ketika passive infrared mendeteksi gerakan maka akan mengirimkan SMS ke pemilik rumah dengan notifikasi SMS "Seseorang Terdeteksi diruang tamu", kemudian akan mengaktifkan sebuah buzzer.

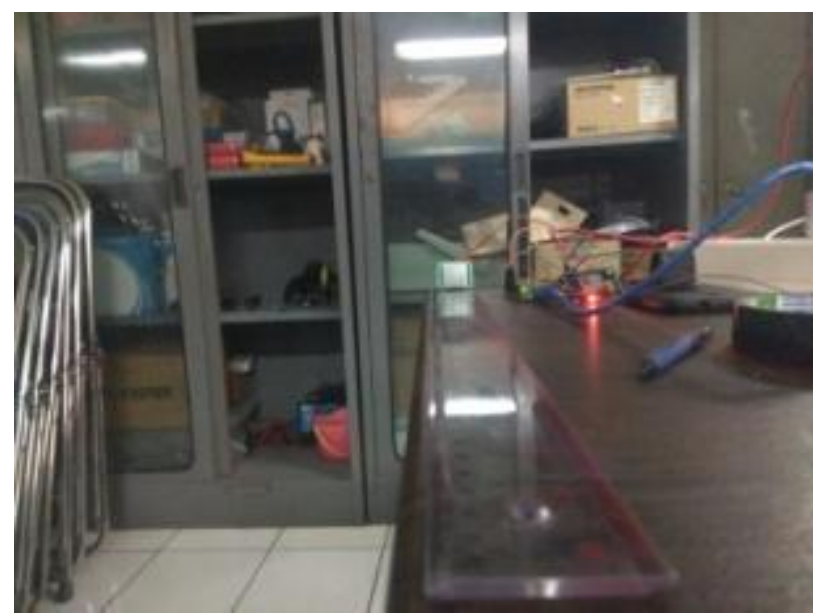


RESISTOR (elektRonika kEndali telekomunikaSI tenaga liSTrik kOmputeR) Vol. 1 No. 2 e-ISSN : 2621-9700, p-ISSN : 2654-2684

Gambar 9. Gambar pengujian sensor passive infrared 1

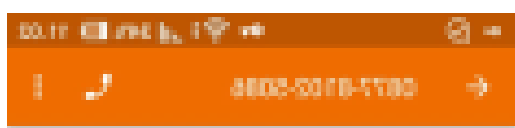

Tabel 3. Pengujian Sensor Passive Infrared 1

\begin{tabular}{|c|c|c|c|c|}
\hline \multirow{2}{*}{ No } & \multirow{2}{*}{$\begin{array}{c}\text { Jarak } \\
(\mathrm{cm})\end{array}$} & \multirow{2}{*}{$\begin{array}{l}\text { Respon } \\
\text { Sensor }\end{array}$} & \multicolumn{2}{|c|}{ Notifikasi } \\
\hline & & & Buzzer & SMS \\
\hline 1 & 10 & $\begin{array}{l}\text { Mendeteksi } \\
\text { pergerakan }\end{array}$ & ON & ON \\
\hline 2 & 20 & $\begin{array}{l}\text { Mendeteksi } \\
\text { pergerakan }\end{array}$ & ON & ON \\
\hline 3 & 30 & $\begin{array}{l}\text { Mendeteksi } \\
\text { pergerakan }\end{array}$ & ON & ON \\
\hline 4 & 40 & $\begin{array}{l}\text { Mendeteksi } \\
\text { pergerakan }\end{array}$ & ON & ON \\
\hline 5 & 50 & $\begin{array}{l}\text { Mendeteksi } \\
\text { pergerakan }\end{array}$ & ON & ON \\
\hline 6 & 60 & $\begin{array}{l}\text { Mendeteksi } \\
\text { pergerakan }\end{array}$ & ON & ON \\
\hline 7 & 70 & $\begin{array}{l}\text { Mendeteksi } \\
\text { pergerakan }\end{array}$ & ON & ON \\
\hline 8 & 80 & $\begin{array}{l}\text { Mendeteksi } \\
\text { pergerakan }\end{array}$ & ON & ON \\
\hline 9 & 90 & $\begin{array}{l}\text { Mendeteksi } \\
\text { pergerakan }\end{array}$ & ON & ON \\
\hline 10 & 100 & $\begin{array}{l}\text { Mendeteksi } \\
\text { pergerakan }\end{array}$ & ON & ON \\
\hline 11 & 110 & $\begin{array}{l}\text { Mendeteksi } \\
\text { pergerakan }\end{array}$ & ON & ON \\
\hline 12 & 120 & $\begin{array}{c}\text { Tidak } \\
\text { Mendeteksi } \\
\text { pergerakan }\end{array}$ & OFF & OFF \\
\hline
\end{tabular}

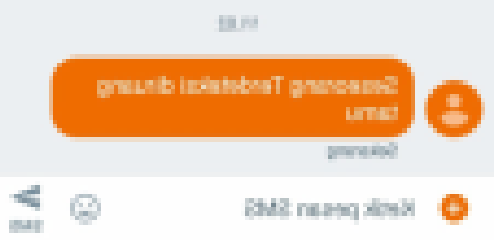

Gambar 10. Tampilan notifikasi SMS sensor Passive Infrared 1

Pada pengujian sensor Passive Infrared (PIR) ini ditujukan untuk mengetahui respon jarak terhadap pergerakan manusia yang ada didalam ruangan tersebut. Dalam pengujian sensor Passiver Infrared (PIR) yaitu dengan menguji jarak pergerakan manusia dari $10 \mathrm{~cm}$ sampai jarak kritis dari sensor Passive Infrared dengan nilai jarak kritis $110 \mathrm{~cm}$. pengujian passive infrared, passive infrared 2 mendeteksi sebuah gerakan manusia pada ruang tamu. Ketika passive infrared mendeteksi gerakan maka akan mengirimkan SMS ke pemilik rumah dengan notifikasi SMS "Seseorang Terdeteksi di ruangkamar", kemudian akan mengaktifkan sebuah buzzer.

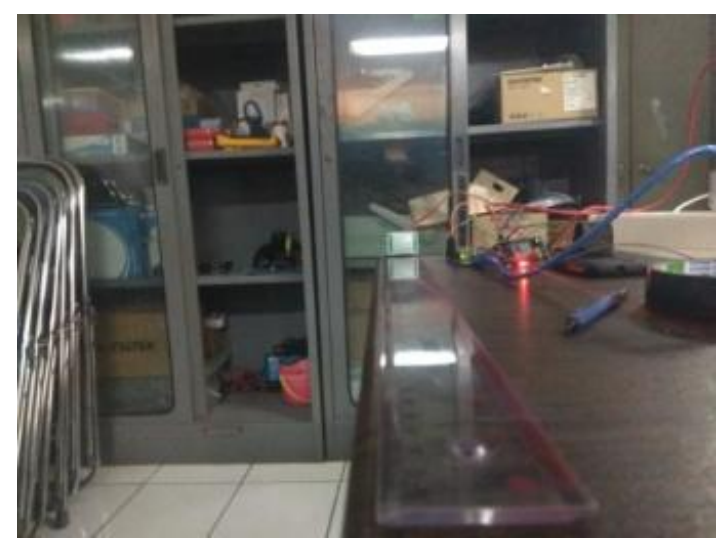

Gambar 11. Gambar pengujian sensor passive infrared 2. 
RESISTOR (elektRonika kEndali telekomunikaSI tenaga liSTrik kOmputeR) Vol. 1 No. 2 e-ISSN : 2621-9700, p-ISSN : 2654-2684

Tabel 4. Pengujian Sensor Passive Infrared2

\begin{tabular}{|c|c|c|c|c|}
\hline \multirow{2}{*}{ No } & \multirow{2}{*}{$\begin{array}{c}\text { Jarak } \\
(\mathrm{cm})\end{array}$} & $\begin{array}{c}\text { Respon } \\
\text { Sensor }\end{array}$ & \multicolumn{2}{|c|}{ Notifikasi } \\
\cline { 5 - 5 } & 10 & $\begin{array}{c}\text { Mendeteksi } \\
\text { pergerakan }\end{array}$ & ON & ON \\
\hline 2 & 20 & $\begin{array}{c}\text { Mendeteksi } \\
\text { pergerakan }\end{array}$ & ON & ON \\
\hline 3 & 30 & $\begin{array}{c}\text { Mendeteksi } \\
\text { pergerakan }\end{array}$ & ON & ON \\
\hline 4 & 40 & $\begin{array}{c}\text { Mendeteksi } \\
\text { pergerakan }\end{array}$ & ON & ON \\
\hline 5 & 50 & $\begin{array}{c}\text { Mendeteksi } \\
\text { pergerakan }\end{array}$ & ON & ON \\
\hline 6 & 60 & $\begin{array}{l}\text { Mendeteksi } \\
\text { pergerakan }\end{array}$ & ON & ON \\
\hline 7 & 70 & $\begin{array}{l}\text { Mendeteksi } \\
\text { pergerakan }\end{array}$ & ON & ON \\
\hline 8 & 80 & $\begin{array}{l}\text { Mendeteksi } \\
\text { pergerakan }\end{array}$ & ON & ON \\
\hline 9 & 90 & $\begin{array}{l}\text { Mendeteksi } \\
\text { pergerakan }\end{array}$ & ON & ON \\
\hline 10 & 100 & $\begin{array}{l}\text { Mendeteksi } \\
\text { pergerakan }\end{array}$ & ON & ON \\
\hline 11 & 110 & $\begin{array}{l}\text { Mendeteksi } \\
\text { pergerakan }\end{array}$ & ON & ON \\
\hline 120 & $\begin{array}{l}\text { Mendak } \\
\text { pergerakan }\end{array}$ & OFF & OFF \\
\hline
\end{tabular}

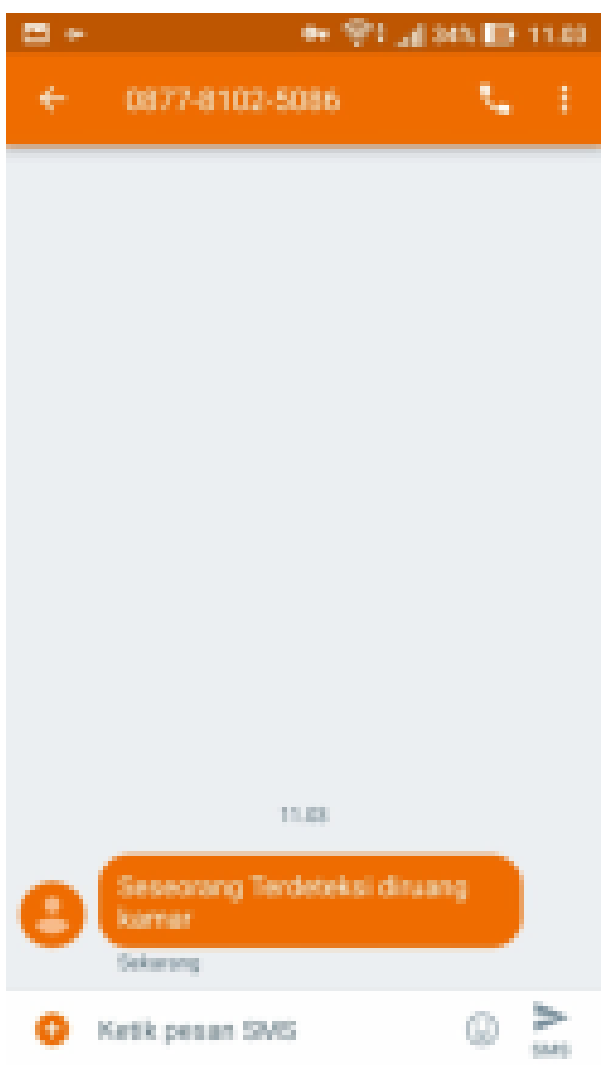

Gambar 12. Tampilan notifikasi SMS sensor Passive Infrared 2

Pada pengujian sensor api ini ditunjukin untuk mengetahui respon pada jarak terhadap deteksi sensor api. Media yang digunakan pada pengujian sensor api ini menggunakan lilin untuk mengukur jarak deteksi tersebut. sensor api akan deteksi dengan jarak 0-120 cm. ketika masih dalam range jarak terdeteksi makan sensor api akan mengirimkan SMS ke pemilik rumah dengan notifikasi SMS "KEBAKARAN" kemudian ketika sensor api deteksi maka akan mengaktifkan buzzer. Berikut adalah gambar pengujian dari sensor api:

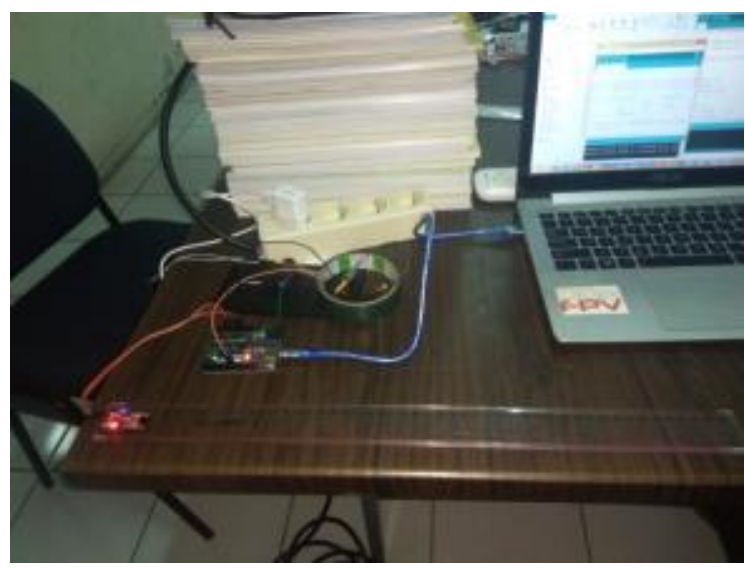

Gambar 13. Pengujian sensor api. 
RESISTOR (elektRonika kEndali telekomunikaSI tenaga liSTrik kOmputeR) Vol. 1 No. 2 e-ISSN : 2621-9700, p-ISSN : 2654-2684

Tabel 5. Pengujian sensor api

\begin{tabular}{|c|c|c|c|c|}
\hline \multirow{2}{*}{$\begin{array}{l}N \\
\mathrm{O}\end{array}$} & \multirow{2}{*}{$\begin{array}{c}\text { Jarak } \\
\text { Pengukur } \\
\text { an Sensor }\end{array}$} & \multirow{2}{*}{$\begin{array}{c}\text { Respon } \\
\text { Sensor } \\
\text { Api }\end{array}$} & \multicolumn{2}{|c|}{ Notifikasi } \\
\hline & & & $\begin{array}{c}\text { Buzz } \\
\text { er }\end{array}$ & $\begin{array}{c}\text { SM } \\
\text { S }\end{array}$ \\
\hline 1. & $10 \mathrm{~cm}$ & $\begin{array}{c}\text { Mendete } \\
\text { ksi Api }\end{array}$ & ON & ON \\
\hline 2. & $20 \mathrm{~cm}$ & $\begin{array}{c}\text { Mendete } \\
\text { ksi Api }\end{array}$ & ON & ON \\
\hline 3. & $30 \mathrm{~cm}$ & $\begin{array}{l}\text { Mendete } \\
\text { ksi Api }\end{array}$ & ON & ON \\
\hline 4. & $40 \mathrm{~cm}$ & $\begin{array}{l}\text { Mendete } \\
\text { ksi Api }\end{array}$ & ON & ON \\
\hline 5. & $50 \mathrm{~cm}$ & $\begin{array}{c}\text { Mendete } \\
\text { ksi Api }\end{array}$ & ON & ON \\
\hline 6. & $60 \mathrm{~cm}$ & $\begin{array}{l}\text { Mendete } \\
\text { ksi Api }\end{array}$ & ON & ON \\
\hline 7. & $70 \mathrm{~cm}$ & $\begin{array}{c}\text { Mendete } \\
\text { ksi Api }\end{array}$ & ON & ON \\
\hline 8. & $80 \mathrm{~cm}$ & $\begin{array}{l}\text { Mendete } \\
\text { ksi Api }\end{array}$ & ON & ON \\
\hline 9. & $90 \mathrm{~cm}$ & $\begin{array}{c}\text { Mendete } \\
\text { ksi Api }\end{array}$ & ON & ON \\
\hline 10 & $100 \mathrm{~cm}$ & $\begin{array}{l}\text { Mendete } \\
\text { ksi Api }\end{array}$ & ON & ON \\
\hline 11 & $110 \mathrm{~cm}$ & $\begin{array}{l}\text { Mendete } \\
\text { ksi Api }\end{array}$ & ON & ON \\
\hline 12 & $120 \mathrm{~cm}$ & $\begin{array}{c}\text { Mendete } \\
\text { ksi Api }\end{array}$ & ON & ON \\
\hline 13 & $130 \mathrm{~cm}$ & $\begin{array}{c}\text { Tidak } \\
\text { Mendete } \\
\text { ksi Api }\end{array}$ & OFF & $\begin{array}{c}\text { OF } \\
\mathrm{F}\end{array}$ \\
\hline
\end{tabular}

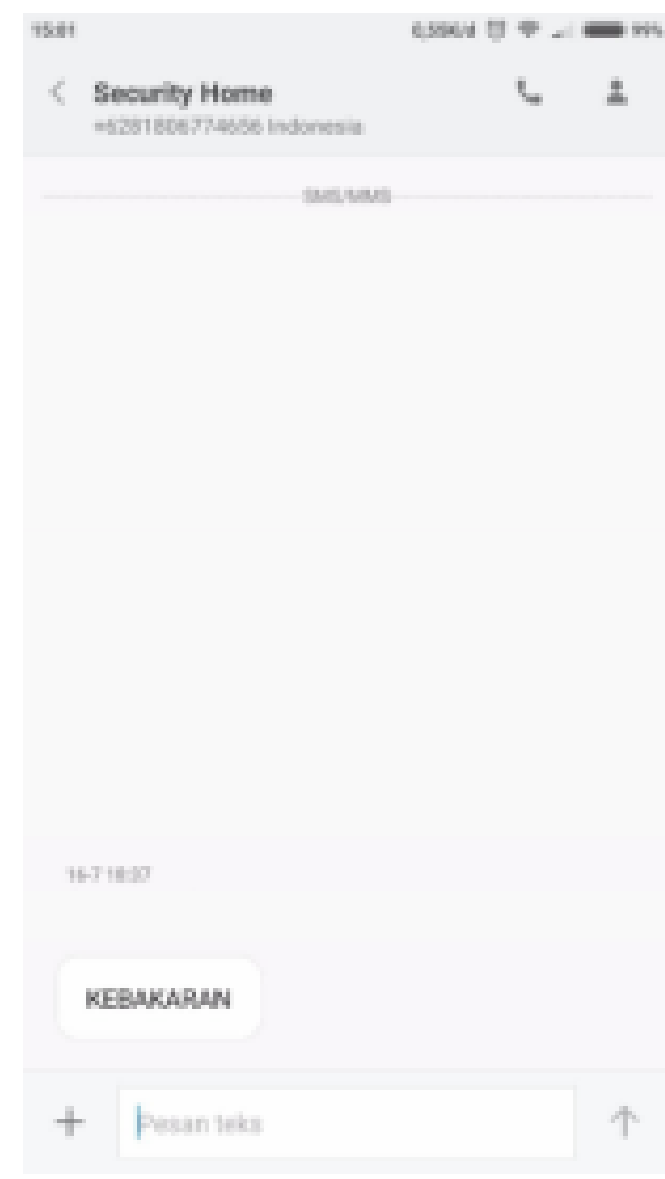

Gambar 14. Tampilan notifikasi SMS sensor api.

Pada pengujian sensor air ini ditunjukin untuk mengetahui respon deteksi sensor air. Media yang digunakan pada pengujian sensor air ini menggunakan penampungan untuk mengukur deteksi pada sensor air. ketika sensor air deteksi maka akan mengirimkan SMS ke pemilik rumah dengan notifikasi SMS "BANJIR" kemudian ketika sensor air deteksi maka akan mengaktifkan buzzer. Berikut adalah gambar pengujian dari sensor air: 
RESISTOR (elektRonika kEndali telekomunikaSI tenaga liSTrik kOmputeR) Vol. 1 No. 2 e-ISSN : 2621-9700, p-ISSN : 2654-2684

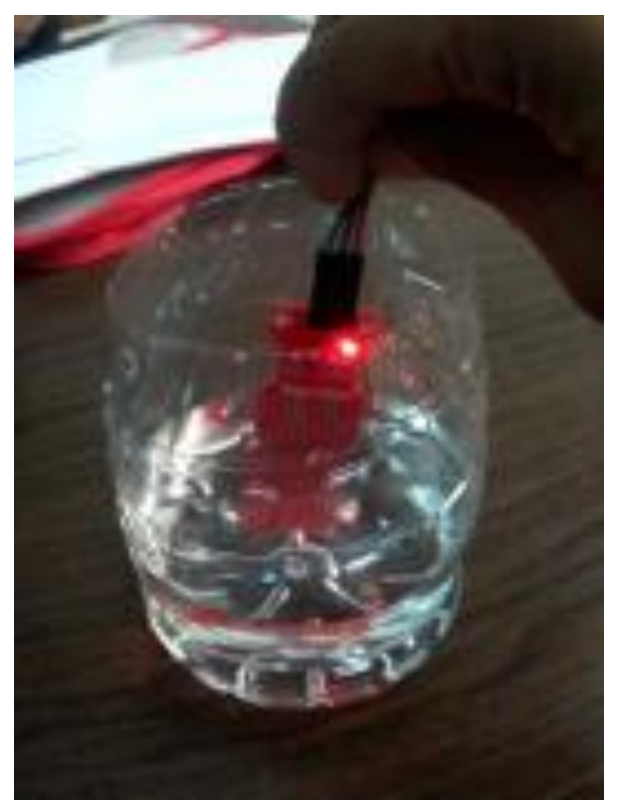

Gambar 15. Pengujian sensor air.

Tabel 6. Pengujian sensor air

\begin{tabular}{|c|c|c|c|}
\hline \multirow{2}{*}{ No } & Respon & \multicolumn{2}{|c|}{ Notifikasi } \\
\cline { 3 - 4 } & Sensor Air & Buzzer & SMS \\
\hline 1. & $\begin{array}{c}\text { Mendeteksi } \\
\text { Air }\end{array}$ & ON & ON \\
\hline 1. & $\begin{array}{c}\text { Mendeteksi } \\
\text { Air }\end{array}$ & ON & ON \\
\hline
\end{tabular}
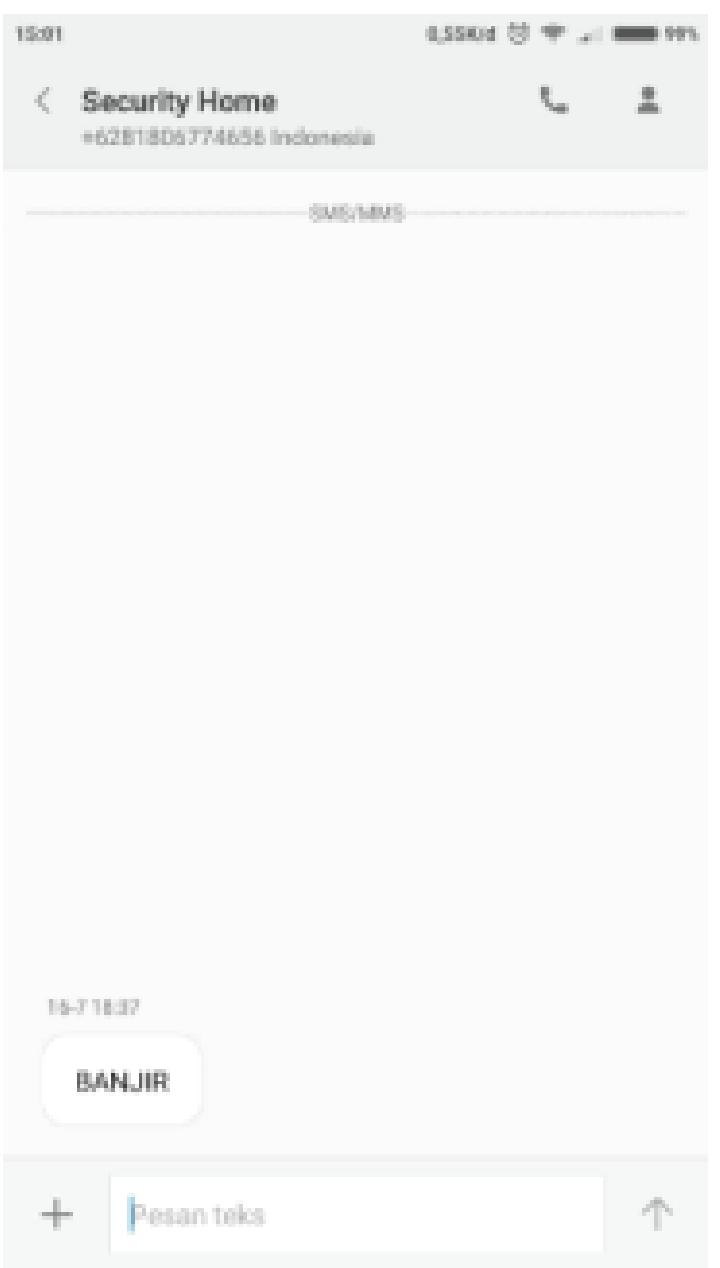

Gambar 16. Tampilan notifikasi SMS sensor air

Pada pengujian sensor gas ini ditunjukan untuk mengetahui respon pada jarak terhadap sensor gas. Media yang digunakan menggunakan adalah gas pada korek api untuk mengukur jarak pada sensor gas. Ketika sensor gas deteksi dengan jarak 0$120 \mathrm{~cm}$. ketika masih dalam range jarak terdeteksi maka sensor api akan mengirimkan SMS ke pemilik rumah dengan notifikasi dengan notifikasi "Gas Bocor" kemudian ketika terdeteksi maka akan mengaktifkan buzzer. Berikut adalah gambar dari pengujian dari sensor gas. 
RESISTOR (elektRonika kEndali telekomunikaSI tenaga liSTrik kOmputeR) Vol. 1 No. 2 e-ISSN : 2621-9700, p-ISSN : 2654-2684

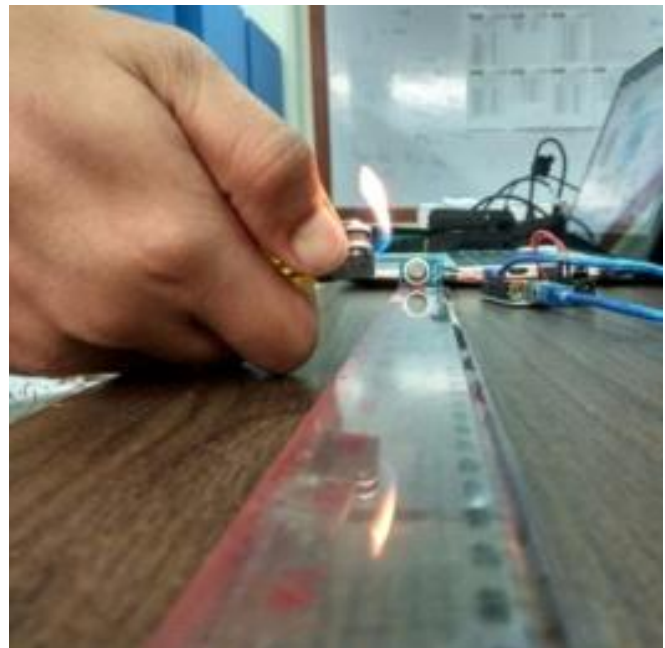

Gambar 17. Pengujian sensor gas

Tabel 7. Pengujian sensor gas.

\begin{tabular}{|c|c|c|c|c|}
\hline N & Jarak & Respon & \multicolumn{2}{|c|}{ Notifikasi } \\
\cline { 4 - 5 } o & $\begin{array}{c}\text { Pengukur } \\
\text { an Sensor }\end{array}$ & $\begin{array}{c}\text { Sensor } \\
\text { Api }\end{array}$ & $\begin{array}{c}\text { Buzz } \\
\text { er }\end{array}$ & $\begin{array}{c}\text { SM } \\
\text { S }\end{array}$ \\
\hline 1. & $10 \mathrm{~cm}$ & $\begin{array}{c}\text { Mendete } \\
\text { ksi Gas }\end{array}$ & ON & ON \\
\hline 2. & $20 \mathrm{~cm}$ & $\begin{array}{c}\text { Mendete } \\
\text { ksi Gas }\end{array}$ & ON & ON \\
\hline 3. & $30 \mathrm{~cm}$ & $\begin{array}{c}\text { Mendete } \\
\text { ksi Gas }\end{array}$ & ON & ON \\
\hline 4. & $40 \mathrm{~cm}$ & $\begin{array}{c}\text { Mendete } \\
\text { ksi Gas }\end{array}$ & ON & ON \\
\hline 5. & $50 \mathrm{~cm}$ & $\begin{array}{c}\text { Mendete } \\
\text { ksi Gas }\end{array}$ & ON & ON \\
\hline 6. & $60 \mathrm{~cm}$ & $\begin{array}{c}\text { Mendete } \\
\text { ksi Gas }\end{array}$ & ON & ON \\
\hline 7. & $70 \mathrm{~cm}$ & $\begin{array}{c}\text { Mendete } \\
\text { ksi Gas }\end{array}$ & ON & ON \\
\hline 8. & $80 \mathrm{~cm}$ & $\begin{array}{c}\text { Mendete } \\
\text { ksi Gas }\end{array}$ & ON & ON \\
\hline 9. & $90 \mathrm{~cm}$ & $\begin{array}{c}\text { Mendete } \\
\text { ksi Gas }\end{array}$ & ON & ON \\
\hline 10 & $100 \mathrm{~cm}$ & $\begin{array}{c}\text { Mendete } \\
\text { ksi Gas }\end{array}$ & ON & ON \\
\hline 11 & $110 \mathrm{~cm}$ & $\begin{array}{c}\text { Mendete } \\
\text { ksi Gas }\end{array}$ & ON & ON \\
\hline 12 & $120 \mathrm{~cm}$ & $\begin{array}{c}\text { Midak } \\
\text { Mendete } \\
\text { ksi Gas }\end{array}$ & OFF & OF \\
\hline
\end{tabular}
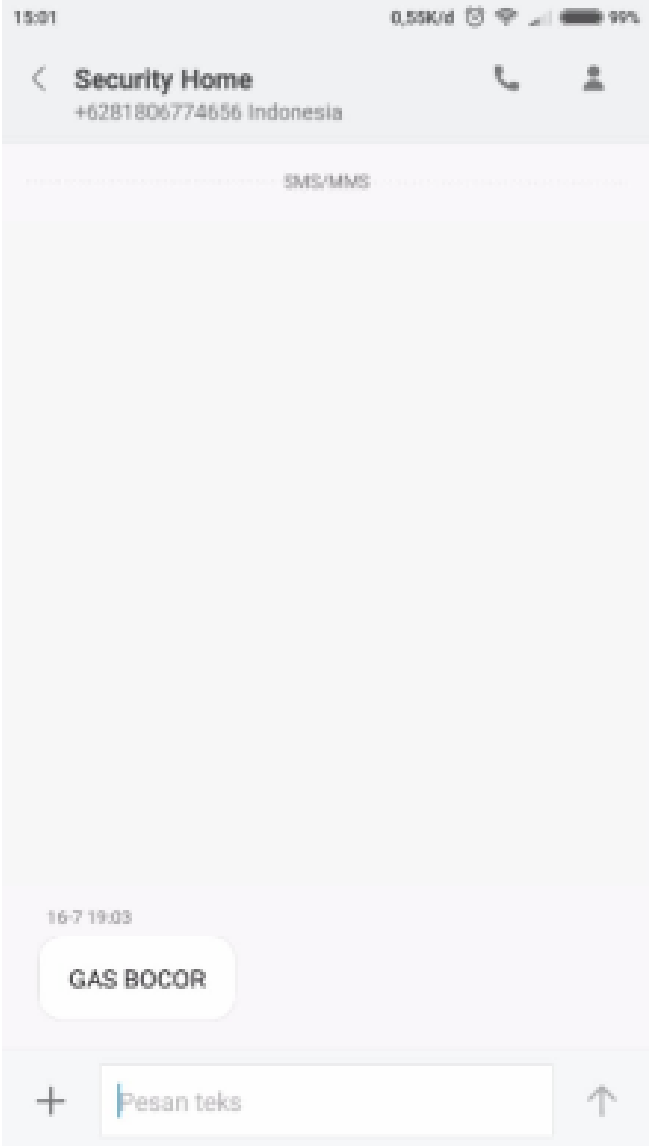

Gambar 18. Tampilan notifikasi SMS sensor gas

\section{KESIMPULAN}

Dari hasil pengujian dan analisa pada prototype yang dibuat, maka didapatkan kesimpulan sebagai berikut:

1. Dalam pengujian RFID didapatkan bahwa RFID bekerja dengan jarak maksimal $5 \mathrm{~cm}$, tetapi sudut deteksi RFID dari $0^{\circ}$ sampai dengan $60^{\circ}$ dan akan deteksi kembali dengan sudut $130^{\circ}$ sampai dengan $180^{\circ}$ untuk membuka sebuah pintu.

2. Dalam pengujian Passive Infrared didapatkan bahwa jarak deteksi sensor Passive Infrared dengan jarak maksimal $110 \mathrm{~cm}$ hal ini berbeda dengan data sheet Passive Infrared yaitu dengan jarak $300 \mathrm{~cm}$ sampai dengan $700 \mathrm{~cm}$. dikarenakan tingkat sensivitas terhadap sensor Passive Infrared dan karakteristik dari sensor Passive Infrared.

3. Dalam pengujian sensor api, dan sensor gas didapatkan bahwa jarak deteksi sensor api, dan sensor gas dengan jarak deteksi maksimal 120 $\mathrm{cm}$ untuk sensor api, sedangkan sensor gas dengan jarak deteksi maksimal $110 \mathrm{~cm}$ untuk sensor gas. 
RESISTOR (elektRonika kEndali telekomunikaSI tenaga liSTrik kOmputeR) Vol. 1 No. 2 e-ISSN : 2621-9700, p-ISSN : 2654-2684

4. Jaringan operator seluler mempengaruhi kinerja SIM 800L supaya tidak mengalami pending terhadap pengiriman SMS.

\section{DAFTAR PUSTAKA}

[1] J. Bangali and A. Shaligram, "Design and Implementation of Security Systems for Smart Home based on GSM technology," International Journal of Smart Home, vol. 7, no. 6, pp. 201-208, Nov. 2013.

[2] C. Bell, Beginning Sensor Networks with Arduino and Raspberry Pi. Apress, 2013.

[3] B. T. W. Utomo and D. S. Saputra, "Simulasi Sistem Pendeteksi Polusi Ruangan Menggunakan Sensor Asap Dengan Pemberitahuan Melalui SMS ( Short Message Service ) Dan Alarm Berbasis Arduino," Jurnal Ilmiah Teknologi dan Informasia ASIA (JITIKA), vol. 10, no. 1, p. 13, 2016.

[4] A. Kadir, Buku Pintar Pemograman Arduino. Yogyakarta. Yogyakarta: MediaKom, 2015.

[5] F. Fadliondi, H. Isyanto, and B. Budiyanto, "Bypass Diodes for Improving Solar Panel Performance," International Journal of Electrical and Computer Engineering (IJECE), vol. 8, no. 5, pp. 2703-2708, 2018.

[6] M. H. Farid, "PENDETEKSI KEBOCORAN TABUNG LPG MELALUI SMS GATEWAY MENGGUNAKAN SENSOR MQ-6 BERBASIS ARDUINO PADA PT BANGUN INTI GEMILANG," STMIK RAHARJA, 2015.

[7] D. Sasmoko and A. Mahendra, "RANCANG BANGUN SISTEM PENDETEKSI KEBAKARAN BERBASIS IoT dan SMS GATEWAY MENGGUNAKAN ARDUINO," Jurnal Simetris, vol. 8, no. 2, Nov. 2017.

[8] Albert Mandagi and S. Immanuel, "PENGGUNAAN SENSOR GAS MQ-2 SEBAGAI PENDETEKSI ASAP ROKOK (MQ-2 SMOKE DETECTOR)," Jurnal Teknik dan Ilmu Komputer, vol. 03, no. 09, p. 7, 2014. 